\title{
Stress, Nutritional Status and Blood Glucose Levels among Patients with Diabetes Mellitus Type 2
}

\author{
Dyah Ayu Kusuma Wardani ${ }^{1}$, Sugiarto $^{2}$, Risya Cilmiaty ${ }^{3}$ \\ ${ }^{1}$ Nutrition Science, Universitas Sebelas Maret, Indonesia \\ ${ }^{2}$ Public Health, Universitas Sebelas Maret, Indonesia \\ ${ }^{3}$ Medical Science, Universitas Sebelas Maret, Indonesia
}

\section{Article Info}

Article history:

Received Aug 7, 2018

Revised Oct 24, 2018

Accepted Nov 19, 2018

\section{Keyword:}

Blood glucose levels

Diabetes mellitus type 2

Nutritional status

Stress

\begin{abstract}
Prevalence of diabetes mellitus (DM) was increased significantly. Stress increased cortisol could increase blood glucose levels while obesity could increase insulin resistance. Objective of this study was to examine correlation of stress and nutritional status with blood glucose levels in patients with DM type 2. Design study was cross sectional using 120 samples from patients with DM type 2 at Polyclinic of Internal Disease Dr. Moewardi Hospital Surakarta during April-May 2018. Variables in this study were stress with perceived stress scale 10 items (PSS-10), nutritional status with body mass index (BMI) and blood glucose levels with fasting blood glucose (FBG) and post-prandial blood glucose (PPBG) examination. The results showed that mean of FBG was $152.9 \pm 63.66 \mathrm{mg} / \mathrm{dL}$ and PPBG was $213.96 \pm 70.17 \mathrm{mg} / \mathrm{dL}$. There was no significant correlation between stress and blood glucose levels, by FBG $(p=0.389)$ and PPBG $(p=0.202)$. However, there was significant correlation between nutritional status and PPBG $(p=0.016)$, but FBG was not significant $(p=0.209)$. In conclusion, there was significant correlation between nutritional status and PPBG in patients with DM type 2, but FBG was not significant. However, there was no significant correlation between stress and blood glucose levels in patients with DM type 2.
\end{abstract}

Copyright (c) 2018 Institute of Advanced Engineering and Science. All rights reserved.

\section{Corresponding Author:}

Dyah Ayu Kusuma Wardani,

Nutrition Science, Universitas Sebelas Maret,

Jl. Ir. Sutami No. 36A Surakarta, Sentral Java, Indonesia.

Email: dyahayukw@student.uns.ac.id

\section{INTRODUCTION}

Based on data from World Health Organization, global prevalence of diabetes mellitus (DM) at adults age more than 18 years old increased from $1980(4.7 \%)$ until $2014(8,5 \%)$ [1]. Based on data from Basic Health Research (RISKESDAS) in 2013, trend of DM prevalence in Indonesia (2.1\%) was higher than $2007(1.1 \%)$. As detail, prevalence of DM at women, higher age and prevalence at urban district showed higher. In particular, Central Java Province, prevalence of DM in 2007 compared to 2013 also increased became $1.9 \%$ [2].

Diabetes mellitus is main cause of blindness, kidney failure, heart attack, stroke and amputation of lower extremities [1]. Classification of DM according to American Diabetes Association (ADA) categorized into 3: DM type 1, DM type 2 dan another type of DM or also called DM type 3 [3]. Ullah, et al. described that in patients with DM type 2 damaged to certain mechanisms that maintain reglucosation of tissue sensitivity to insulin, resulting in impaired insulin secretion from pancreatic beta cells and impaired insulin action through insulin resistance [4].

Basic Health Research in 2013 also reported prevalence of psychological distress in Central Java Province was 4.7\% [2]. Ramkisson, et al. found that psychological distress affects metabolic control in patients with DM, thereby increasing risk of long-term complications [5]. Trisnawati and Setyorogo [6] 
described that increased risk of DM in condition of stress caused by excessive production of cortisol when experienced stress. This excessive cortisol production would cause sleeplessness, depression, decreased blood pressure, weakness and over appetite. Therefore, generally people who experience long stress would have tendency to overweight which was one of risk factors for DM [6]. Ulrich-Lai, et al. [7] described that stress signals, including glucocorticoids and corticotropin-releasing factor (CRF), targeted dopamine neurons in mesolimbic region. Modulation of dopamine prefrontal striatum reglucosation increased susceptibility of food addiction as a "reward system" through very tasty food intake (high calorie density foods containing high glucose, carbohydrates and fat) which referred as "comfort food" [7]. Cortisol could affect directly blood glucose level in a person. Increased cortisol could cause stimulation of gluconeogenesis and decrease of glucose uptake by cells. Both of these could cause increasing concentration of glucose circulated in the blood [8].

Each individual, mood and mental condition is one of factors that could influence food intake [9]. In patients with DM type 2, stress was associated with higher intake of sweet foods. Cortisol was associated with higher intake of saturated fats and sweet foods. Apart from DM, stress was associated with circulated insulin and higher body mass index (BMI) [10]. Misnadiarly explained that stress and anxiety were assumed could cause obesity [11]. Awad, et al. pointed that obesity is main risk factor for two-thirds of DM type 2 incidence [12]. In obese, non-esterified fatty acids (NEFA) levels, glycerol, hormones, cytokines, proinflammatory agents and other factors associated with insulin resistance increased [13]. Therefore, we examined correlation of stress and nutritional status with blood glucose levels in patients with DM type 2 .

\section{RESEARCH METHOD}

This study was a cross sectional design conducted at Dr. Moewardi Hospital Surakarta since April until May 2018. Population of this study was all patients with DM type 2 at Polyclinic Internal Disease Dr. Moewardi Hospital Surakarta. Samples of 120 people were taken by consecutive sampling method. Nevertheless, only 111 samples were able to be analyzed because 9 patients did not complete blood glucose levels examination post-prandial blood glucose test, so that they were excluded from this study. Samples selected based on inclusion and exclusion criteria. Inclusion criterias: (1) outpatients at Polyclinic Internal Disease Dr. Moewardi Hospital Surakarta with medical diagnosis of DM type 2; (2) adult age (>19 years); (3) not physically and mentally disabled; (4) taking DM drugs; and (5) not sick. Exclusion criterias: (1) menstruation; (2) elderly (> 60 years); and (3) do not complete all research procedures.

Stress in this study was measured using perceived stress scale 10 items (PSS-10) questionnaire. Results using PSS-10 is add up all total score of each question, except for numbers 4, 5, 7 and 8 given opposite score of scale used $(0=4,1=2,2=2,3=1$ and $0=4)$. Total PSS-10 score then categorized as mild, moderate and severe stress [14].

Nutritional status was determined by body mass index (BMI), i.e. weight $(\mathrm{kg})^{2} /$ height $(\mathrm{m})$. Data of body weight and height were taken from measurements of hospital staff. This was a standard procedure in Dr. Moewardi Hospital Surakarta where every outpatient was measured for anthropometry in the registration section on each visit. Category of BMI in this study refers to BMI categorization from WHO for Asia-Pacific [15].

Blood glucose levels examination performed in this study were fasting blood glucose (FBG) and 2-hour post-prandial blood glucose (PPBG) tests in $\mathrm{mg} / \mathrm{dL}$. Data of blood glucose levels were also taken from examination by hospital staff. This was also a standard procedure in Dr. Moewardi Hospital Surakarta where every patient with DM type 2 performed blood glucose tests in laboratory one day before routine control was carried out. The results of examination of blood glucose levels then categorized into normal, moderate and high [16]. Statistical analysis used in this study was Kendall-tau correlation using SPSS 16. All procedures in this study have been approved by Ethics Committee Dr. Moewardi Hospital/Faculty of Medicine Universitas Sebelas Maret.

\section{RESULTS AND DISCUSSION}

Table 1 shows mean of stress, BMI, FBG and PPBG. Mean of stress based on total score of PSS-10 is $14.50 \pm 5.50(95 \% \mathrm{CI}=13.47-15.54)$. Mean of $\mathrm{BMI}$ was $25.83 \pm 4.2 \mathrm{~kg} / \mathrm{m} 2\left(95 \% \mathrm{CI}=25.03-26.63 \mathrm{~kg} / \mathrm{m}^{2}\right)$. Mean of blood glucose levels by FBG was $152.91 \pm 63.66 \mathrm{mg} / \mathrm{dL}(95 \% \mathrm{CI}=140.94-164.88 \mathrm{mg} / \mathrm{dL})$ and PPBG was $213.96 \pm 70.17 \mathrm{mg} / \mathrm{dL}(95 \% \mathrm{CI}=200.76-227.15 \mathrm{mg} / \mathrm{dL})$. Table 2 describes results of statistical analysis from correlation of stress and nutritional status with blood glucose levels by FBG. Kendall-tau correlation as indicator of significance level. Table 3 also shows Kendall-tau correlation of stress and nutritional status with blood glucose levels by PPBG. 
Table 1. Mean of Stress, Body Mass Index, Fasting Blood Glucose and Post-prandial Blood Glucose

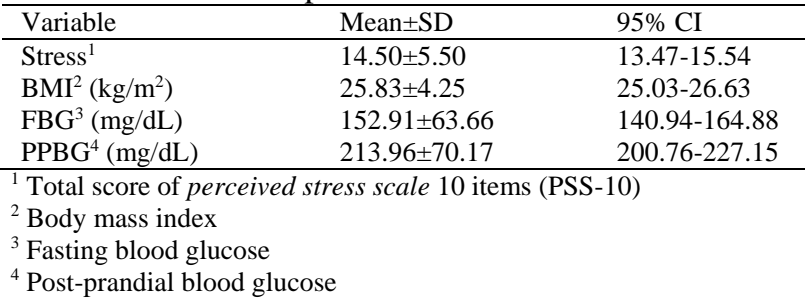

Table 2. Correlation of Stress and Nutritional Status with Blood Glucose Levels by Fasting Blood Glucose

\begin{tabular}{|c|c|c|c|c|c|c|c|c|}
\hline \multirow{3}{*}{ Variable } & \multicolumn{6}{|c|}{ Fasting blood glucose ${ }^{3}$} & \multirow{3}{*}{$t^{4}$} & \multirow{3}{*}{$p$} \\
\hline & \multicolumn{2}{|c|}{ Normal } & \multicolumn{2}{|c|}{ Moderate } & \multicolumn{2}{|c|}{ High } & & \\
\hline & $\mathrm{n}$ & $\%$ & $\mathrm{n}$ & $\%$ & $\mathrm{n}$ & $\%$ & & \\
\hline \multicolumn{9}{|l|}{ Stress $^{1}$} \\
\hline Mild & 10 & 32.3 & 6 & 33.3 & 26 & 41.9 & & \\
\hline Moderate & 21 & 67.7 & 12 & 66.7 & 35 & 56.5 & -0.078 & 0.389 \\
\hline Severe & 0 & 0 & 0 & 0 & 1 & 1.6 & & \\
\hline Total & 31 & 100 & 18 & 100 & 62 & 100 & & \\
\hline \multicolumn{9}{|l|}{ Nutritional status $^{2}$} \\
\hline Underweright & 0 & 0 & 1 & 5.6 & 2 & 3.2 & & \\
\hline Normal & 5 & 16.1 & 4 & 22.2 & 9 & 14.5 & 0.088 & 0.292 \\
\hline Overweight & 10 & 32.3 & 4 & 22.2 & 9 & 14.5 & & \\
\hline Obese & 16 & 51.6 & 9 & 50 & 42 & 67.7 & & \\
\hline Total & 31 & 100 & 18 & 100 & 68 & 100 & & \\
\hline
\end{tabular}

${ }^{1}$ Mild $\leq 13$, moderate $=14-26$, severe $>26$

${ }^{2}$ Underweight $<18.5 \mathrm{~kg} / \mathrm{m}^{2}$, normal $=18.5-22.9 \mathrm{~kg} / \mathrm{m}^{2}$, overweight $=23-24.9 \mathrm{~kg} / \mathrm{m}^{2}$, obese $\geq 25 \mathrm{~kg} / \mathrm{m}^{2}$

${ }^{3}$ Normal $<110 \mathrm{mg} / \mathrm{dL}$, moderate $=110-125 \mathrm{mg} / \mathrm{dL}$, high $\geq 126 \mathrm{mg} / \mathrm{dL}$

${ }^{4}$ Kendall-tau correlation

Table 3. Correlation of Stress and Nutritional Status with

Blood Glucose Levels by Post-prandial Blood Glucose

\begin{tabular}{|c|c|c|c|c|c|c|c|c|}
\hline \multirow{3}{*}{ Variable } & \multicolumn{6}{|c|}{ Post-prandial blood glucose ${ }^{3}$} & \multirow{3}{*}{$t^{4}$} & \multirow{3}{*}{$p$} \\
\hline & \multicolumn{2}{|c|}{ Normal } & \multicolumn{2}{|c|}{ Moderate } & \multicolumn{2}{|c|}{ High } & & \\
\hline & $\mathrm{n}$ & $\%$ & $\mathrm{n}$ & $\%$ & $\mathrm{n}$ & $\%$ & & \\
\hline \multicolumn{9}{|l|}{ Stress $^{1}$} \\
\hline Mild & 6 & 35.3 & 9 & 45 & 27 & 36.5 & & \\
\hline Moderate & 11 & 64.7 & 11 & 55 & 46 & 62.2 & 0.110 & 0.202 \\
\hline Severe & 0 & 0 & 0 & 0 & 1 & 1.4 & & \\
\hline Total & 17 & 100 & 20 & 100 & 74 & 100 & & \\
\hline \multicolumn{9}{|l|}{ Nutritional status ${ }^{2}$} \\
\hline Underweright & 0 & 0 & 0 & 0 & 3 & 4.1 & & \\
\hline Normal & 6 & 35.3 & 4 & 20 & 8 & 10.8 & 0.209 & $0.016^{*}$ \\
\hline Overweight & 6 & 35.3 & 4 & 20 & 13 & 17.6 & & \\
\hline Obese & 5 & 29.4 & 12 & 60 & 50 & 67.6 & & \\
\hline Total & 17 & 100 & 20 & 100 & 74 & 100 & & \\
\hline
\end{tabular}

${ }^{1}$ Mild $\leq 13$, moderate $=14-26$, severe $>26$

${ }^{2}$ Underweight $<18.5 \mathrm{~kg} / \mathrm{m}^{2}$, normal $=18.5-22.9 \mathrm{~kg} / \mathrm{m}^{2}$, overweight $=23-24.9 \mathrm{~kg} / \mathrm{m}^{2}$, obese $\geq 25 \mathrm{~kg} / \mathrm{m}^{2}$

${ }^{3}$ Normal $<145 \mathrm{mg} / \mathrm{dL}$, moderate $=145-179 \mathrm{mg} / \mathrm{dL}$, high $\geq 180 \mathrm{mg} / \mathrm{dL}$

${ }^{4}$ Kendall-tau correlation

* Significant $p<0.05$

\subsection{Stress and blood glucose levels}

In this study, only 1 patient perceived severe stress $(0.9 \%)$, others perceived mild stress 42 patients (37.8\%) and moderate stress 68 patients $(61.3 \%)$. Tables 2 and 3 showed no significant correlation between stress and blood glucose levels, both FBG $(p=0.389)$ and PPBG $(p=0.202)$. In this study, there was no significant correlation between stress and blood glucose levels in patients with DM type 2, both using FBG and PPBG tests. This result was different from Derek, et al. who found that there was association between stress levels and blood glucose levels in patients with DM type 2 at Pancaran Kasih Hospital GMIM Manado [17]. Physiologically, Sinha \& Jastebroff explained that stress responses arise through two stress pathways interaction. First, activation of hypothalamic-pituitary-adrenal (HPA) axis that relesead corticotropin-releasing factor (CRF) from paraventricular nucleus (PVN) hypothalamus, then stimulates 
secretion of adrenocorticotropin hormon (ACTH) from anterior pituitary gland, which stimulates glucocorticoid secretion (cortisol or corticosterone) from the adrenal gland. Second, autonomic nervous system was coordinated by symathoadrenal medullary (SAM) and parasympathetic systems [18]. Chronic activation of HPA axis could affect glucose metabolism and cause insulin resistance, resulting in changes in hormones related to appetite (such as leptin and ghrelin) and food neuropeptides (such as NPY) [7]. Pscychological stress could increase ghrelin in serum. Ghrelin have orexigenic effect that could increasing appetite [19]. Cortisol could affect directly blood glucose level in a person. Increased cortisol could cause stimulation of gluconeogenesis and decrease of glucose uptake by cells. Both of these could cause increasing concentration of glucose circulated in the blood [8]. There was relationship between homocysteine and cortisol related to psychological factors in patients with DM type 2. Kontoangelos et al. [20] found that high cortisol levels were associated with increase in conflict. Cortisol in patients with controlled DM increased when increase in phobic anxiety was measured by the sympton checklist-90-R scale (SCL-90-R). Stress or psychological conditions due to other things (such as trauma, surgery, injection, anesthesia and hypoglycemia) and depression stimulated releasing of CRF from hypothalamus in the brain and triggered ACTH by pituitary gland, which caused adrenal glands to produce hormones, including cortisol by the adrenal cortex [20]. Apart from DM, stress was associated with circulated insulin and higher BMI [21].

In sample of this study, patients did not perceive severe stress, so increasing blood glucose levels in this sample was not affected by stress but caused by another factors. Nonetheless, as seen in Table 3 and 4 that patients with moderate stress and high blood glucose levels, both FBG and PPBG, were seen more than patients with mild stress. Ramkisson et al. found that factors contributing to high psychosocial stress were low education, unemployed, women, presence in public sector and high levels of HbA1c. Psychosocial stress affected metabolic control in patients with DM, thus increasing risk of long-term complications [5].

\subsection{Nutritional status and blood glucose levels}

Table 2 showed no significant relationship between nutritional status and FBG $(p=0.292)$, but Table 3 showed that there was a significant relationship between nutritional status and PPBG $(p=0.016)$. This study found significant correlation between nutritional status based on BMI and blood glucose levels based on PPBG in patients with DM type 2. This result clarified Al-Goblan, et al. statement that obesity based on BMI was very closely related to DM and insulin resistance, both DM type 1 and type 2. In obese, NEFA levels, glycerol, hormones, cytokines, proinflammatory agents and other factors associated with insulin resistance increased [13]. According to Wynne, et al., circulated insulin levels were largely determined by peripheral insulin sensitivity and associated with total body fat deposits and fat distribution. Visceral fat was a major determinant of insulin sensitivity [19]. Awad, et al. pointed that obesity is main risk factor for two-thirds of DM type 2 incidences [12]. In addition, this study also analyzed correlation between nutritional status and FBG, but p-value of statistical analysis using Kendall-tau correlation showed insignificant. However, as seen in Table 2 that obese patient tend to have higher blood sugar levels than in other nutritional status categories. Although not statistically significant, situation in Table 2 was not much different from correlation of nutritional status with PPBG in Table 3.

Obesity was noted to be very common among patients with DM. This was very detrimental and counter-productive particularly for patients with DM type 2 and this made control of their blood sugar more elusive [23]. Analysis of obesity effects, measured by BMI, showed that its diabetogenic effect. Mean of PPBG ranged from $5.8 \mathrm{mmol} / 1$ in men who were in the highest tertile of weight at one year but the lowest tertile of current BMI $\left(<25.4 \mathrm{~kg} / \mathrm{m}^{2}\right)$, to $7.7 \mathrm{mmol} / 1$ in men in the lowest tertile of weight at one year and the highest tertile of current BMI $\left(>28 \mathrm{~kg} / \mathrm{m}^{2}\right)$ [24]. Both high proportion of body fat and predominance of central obesity were associated with insulin resistance. A high proportion of Asian people have both these characteristics, and might also have pancreatic $\beta$-cell secretory defects. Impaired insulin secretion might be induced by insufficient $\beta$-cell mass, by functional defects within the $\beta$ cells themselves, or both [25].

The weakness of this study was using cross sectional design that weak to explain cause and effect of an association. Moreover, number of samples with severe stress was inadequate and could not describe the results well. Further study on other samples that have higher stress level would likely to illustrate better results. This study using two indicators of blood glucose levels (FBG and PPBG) to emphasize the results of the study. The results by FBG test showed insignificant correlation of nutritional status with blood glucose levels, but the results by PPBG test could confirm correlation between nutritional status and blood glucose levels by giving significant result. PPBG test was an examination to assess pancreatic function or insulin was released by pancreas to neutralize glucose. Blood glucose levels would increase after meals and would gradually normalize after approximately 2 hours [26]. This study used inclusion and exclucion criterias to control counfounding factors, such as age, sex and medication. Samples taken in this study was from age adult group (19-60 years). Diabetes mellitus in elderly was metabolically different with DM in other age groups, so different therapeutic approach was needed in this age group [27]. In elderly ( $\geq 60-65$ years), DM 
was an alarming public health problem in developing countries. Complications and comorbidities of DM were more common in elderly patients with DM than in younger patients [28]. Medication also have effect on blood glucose levels in patients with DM type 2, so only patients who taking DM drugs were taken as sample in this study. Sex distribution of patients who participated in this study was fairly balanced, men $45 \%$ and women $55 \%$.

\section{CONCLUSION}

There was significant correlation between nutritional status and post-prandial blood glucose in patients with diabetes mellitus (DM) type 2, but fasting blood glucose was not significant. There was no significant correlation of stress with fasting blood glucose and post-prandial blood glucose in patients with DM type 2. Patients with DM type 2 should more attention about their nutritional status so that support controling blood glucose levels. Further study should consider about better study design and number of samples in each stress group in order to achive better results.

\section{ACKNOWLEDGEMENTS}

We acknowledge to all staff of Dr. Moewardi Hospital Surakarta, especially to Training and Education Division, Polyclinic Internal Disease, Medical Record Division and Laboratory. All patients with DM type 2 at Polyclinic of Internal Disease Dr. Moewardi Hospital Surakarta who contributed to this study. Special thanks to Prof. Dr. Mohammad Fanani, dr., Sp.KJ(K) and Dr. Dra. Diffah Hanim, M.Si. for advices and suggestions to this study improvement. Master Program of Nutrition Science, Postgraduate School, Universitas Sebelas Maret for help to conduct this study.

\section{REFERENCES}

[1] World Health Organization (WHO), "Diabetes", http://www.who.int/, 2017, accessed Oct 20, 2017.

[2] Ministry of Health Republic Indonesia, "Basic Health Research (RISKESDAS) 2013", http://www.depkes.go.id/, 2013, accessed Oct 222017.

[3] American Diabetes Association (ADA), "Diagnosis and Classification of Diabetes Mellitus", Diabetes Care, vol.31, suppl.1, pp. S62-S67, 2009.

[4] Ullah, A., Khan, A., Khan, I., "Diabetes Mellitus and Oxidative Stress-A Concise Review", Saudi Pharm J, vol.24, pp.547-553, 2016.

[5] Ramkisson, S., Pillay, B.J., Sartorius, B., "Psychosocial Stress in South African Patients with Type 2 Diabetes", Journal of Insulin Resistance, vol.1, no.1, a17, 2016.

[6] Trisnawati, S.K., Setyorogo, S., "Factors of Type II Diabetes Mellitus at Primary Health Center Cengkareng Subdistrict, West Jakarta in 2012 (in Bahasa)" Jurnal Ilmiah Kesehatan, vol.5, no.1, pp.6-11, 2013.

[7] Ulrich-Lai, Y.M., Fulton, S., Wilson, M., Petrovich, G., Rinaman, L., "Stress Exposure, Food Intake, and Emotional State", Stress, vol.18, no.4, pp.381-399, 2016.

[8] Guyton, A.C., Hall, J.E., "Medical Physiology Textbook 9th Edition”, editor I. Setiawan, Jakarta: EGC, 1997.

[9] Barasi, M.E., "At a Glance Ilmu Gizi (Nutrion)”, translated by H. Halim, Jakarta: Erlangga, 2009.

[10] Laugero, K.D., Falconc, L.M., Tucker, K.L., "Relationship between Perceived Stress and Dietary and Activity Patterns in Older Adults Participating in the Boston Puerto Rican Health Study," Appetite, vol.56, no.1, pp.194-204, 2011

[11] Misnadiarly, "Obesity as Risk Factor Some Diseases, ed. 1”, Jakarta: Pustaka Obor Populer, 2007.

[12] Awad, S.F., O'Flaherty, M., Critchley, J., Abu-Raddad, L.J., "Forecasting the Burden of Type 2 Diabetes Mellitus in Qatar to 2050: a Novel Modeling Approach”, Diabetes Res Clin Pract, vol.137, pp.100-108, 2018.

[13] Al-Goblan, A.S., Al-Alfi, M.A., Khan, M.Z., "Mechanism Linking Diabetes Mellitus and Obesity," Diabetes Metab Syndr Obes, vol.7, pp.587-591, 2014.

[14] Perceived Stress Scale, 2017, https://das.nh.gov/wellness/, accessed May 20, 2018.

[15] World Health Organization (WHO), "The Asia-Pacific Perspective: Redefining Obesity and Its Treatment", Sidney: Health Communications Australia Pty Limited, 2000, http://www.wpro.who.int/, accessed May 20, 2018.

[16] Indonesian Endocrinology Association (PERKENI), "Consensus on the Management and Prevention of Diabetes Mellitus Type 2 in Indonesia”, 2000, http://pbperkeni.or.id/, accessed May 20, 2018.

[17] Derek, M.I., Rottie, J.V., Kallo, V., "Relationship between Stress Levels and Blood Glucose Levels in Patients with Diabetes Mellitus Type II at Pancaran Kasih Hospital GMIM Manado", e-Journal Keperawatan, vol.4, no.1, 2017.

[18] Sinha, R., Jastebroff, A.M., "Stress as a Common Risk Factor for Obesity and Addiction," Biol Psychiatry, vol.73, no.9, pp.827-835, 2013.

[19] Rouch, V., Bloch, M., Rosenberg, N., Gilad, S., Limor, R., Stern, N., Greenman, Y., "The Acute Ghrelin Response to a Psychological Stress Challenge does not Predict the Post-stress Urge to Eat," Psychoneuroendocrinology, vol.32, no.6, 693-702, 2007. 
[20] Kontoangelos, K., Papageorgiou, C.C., Raptis, A.E., Tsiotra, P., Lambadiari, V., Papadimitriou, G.N., Rabavilas, A.D., Dimitriadis, G., Raptis, S.A., "Homocysteine, Cortisol, Diabetes Mellitus and Psychopathology", Journal of Diabetes Research, vol.2015, 2015.

[21] Laugero, K.D., Falconc, L.M., Tucker, K.L., "Relationship between Perceived Stress and Dietary and Activity Patterns in Older Adults Participating in the Boston Puerto Rican Health Study", Appetite, vol.56, no.1, pp.194-204, 2011.

[22] Wynne, K., Stanley, S., McGowan, B., Bloom, S., “Appetite Control”, Journal of Endocrinol, vol.184, pp.291-318, 2005.

[23] Wahomi, E., Kibomi, W., "Nutritional Knowledge and Nutritional Status of Diabetes Type 2 Patients In Kikuyu Mission Hospital, Nairobi, Kenya," International Journal Health Science Research, vol.6, no.10, pp. 229-234, 2016.

[24] Hales, C.N., Barker. D.J., "Type 2 (non-insulin-dependent) Diabetes Mellitus: the Thrifty Phenotype Hypothesis", Diabetologia, vol.35, pp.595-601, 1992.

[25] Yoon, K., Lee, J., Kim, J., Cho, J.H., Choi, Y., Ko, S., Zimmet, P., Son, H, "Epidemic Obesity and Type 2 Diabetes in Asia", Lancet, vol.368, pp.1681-1688, 2006.

[26] Hardjoeno, H., "Interpretation of Diagnostic Laboratory Test Results", Jakarta: EGC, 2003. In Chahyani, M., "The Difference between Results of Glucose Examination with GOD-PAP Method and Strip Way at Health Analyst Students of Health Polythechnic Tanjungkarang," [Thesis], Semarang: Muhammadiyah Semarang University, 2017, http://repository.unimus.ac.id, accessed Jun 192018

[27] Kurniawan, I., "Type 2 Diabetes Mellitus in Elderly," Journal of the Indonesian Medical Association, vol.60, no.12, pp.576-584, 2010

[28] Chentli, F., Azzoug, S., Mahgoun, S., "Diabetes Mellitus in Elderly," Indian Journal of Endocrinology and Metabolism, vol.19, no.6, pp.744-752, 2015. 